\title{
FINANCIAL ACCOUNTING INFORMATION SYSTEM FOR SMES WITH MODEL-BASED FINANCIAL REPORTING SAK ETAP
}

\author{
Agus Dwi Sasono ${ }^{1}$, Arasy Alimudin ${ }^{2}$, Made Kamisutara ${ }^{3}$, Immah Inayati ${ }^{4}$ \\ ${ }^{1}$ Accounting Department, ${ }^{2}$ Management Department, ${ }^{3}$ Information System Department, \\ ${ }^{4}$ Information System DepartmentNarotama University
}

\begin{abstract}
The development of small and medium enterprises (SMEs) plays an important role in improving the economy of Indonesia. According to the study the Central Bureau of Statistics, demographic trends will increase Indonesia. This could be a threat and an opportunity. Demographic trends threat when the increase is only being targeted overseas businessmen. An opportunity when the Indonesian people were able to take this opportunity and vying to become an entrepreneur. SMEs, which independent small and medium sized enterprises constitute the most appropriate form of business for the nation of Indonesia. The great potential of MSMEs implementation is hampered by the inability of businesses in obtaining capital, which is one of the reasons, is the inability of MSMEs in presenting the financial statements. This is due to limited human resource capacity SMEs in understanding and preparing financial accounting statements according to standards known to be difficult for small and medium businesses.

To solve these problems, then there needs to be a financial information system for SMEs applied for is user friendly, easy to use and is based on financial standards more easily and $\mathrm{d}=$ simple, the Financial Accounting Standards for Entities without Public Accountability (SAK ETAP). This paper discusses Reporting Model, functional design and interface design for a system of financial information of SMEs on the basis of SAK-ETAP.
\end{abstract}

Keywords: SMEs, SAK-ETAP, user friendly, Interface Design

\section{Introduction}

Indonesia is a nation that has great potential to become a great nation, especially in the economic field in spite of all sorts of complex problems faced. One of the demographic factors trends that are owned by the Indonesian nation. Based on data from the Central Statistics Agency (BPS), the ratio of productive age group will increase from $67.4 \%$ in 2010 (total population of 237.6 million) to $69.7 \%$ in 2025 . This fact can give us an idea as well as projections of the form periods of economic gold in the so-called demographic bonus era (demographic dividend), which this time could push Indonesian macro economy. (Lestari). Then need substantial support from various parties in an effort to boost entrepreneurship in society, so that the demographic trends are not only made the nation of Indonesia as a market of foreign parties who would have been eyeing Indonesia as a target market, yet is also a 
potential for Indonesia to become a nation that is able to produce and expand the market even to overseas.

Small and medium-sized businesses, is the work done by most people in Indonesia because it does not require large capital and a simple process. The existence of these types of businesses has role of strategic importance for the economic growth of countries, both developing and developed countries. Then the improvement efforts should continue to be supported and encouraged in order to maximize its potential.

According to Suryana (2007: 71), the essence of the existence of small businesses in the economy, among others: (1) As a tool for strengthening the national economy through various linkages need; (2) small businesses function as a transformer between sectors that have links to the front and rear; (3) small businesses can improve economic efficiency, especially in absorbing the available resources; (4) small businesses as a means of distribution of national income and means of equalization sought (wealth creation process), because the numbers are scattered throughout the country.

However, in practice many difficulties and obstacles faced by SMEs. Research conducted by the State Ministry of KUKM with the BPS (2003) states that there are $72.47 \%$ of SMEs in running and developing a business experiencing business difficulties, and the remaining $27.53 \%$ no significant problems. Still on the same study, the ratio of $72.47 \%$ which is experiencing difficulties these efforts, it is suspected that SMEs face problems, namely: (1) capital, amounting to $51.09 \%$; (2) marketing, 34.72\%; (3) raw materials, $8: 59 \%$; (4) employment, 1:09\%; (5) distribution transportation, 0:22\%; and (6) other amounted to 3.93\%. From this study it can be concluded that more than half of SMEs facing capital problems. The study also mentions that on to overcome the problems of this capital, of all SMEs, known as much as 17:50\% SMEs increase their capital by accessing the capital of the bank, and the remaining $82.50 \%$ to get a loan from the institution Non-banks such as Credit Unions (KSP), singles , family, venture capital and others.

One of the top problems facing SMEs in obtaining capital is the inability of MSMEs in presenting the financial statements that are valid, accurate and in accordance with financial standards could convince the owners of capital in equity investments. Many small and medium businesses who think that the problem of fund management is easy and simple, but the preparation and presentation of financial statements is difficult and complicated. Benjamin (1990) argued that the weakness of SMEs in preparing financial reports due to lack of education and lack of understanding of financial accounting standards (GAAP). In response to this problem by bonding with the publication of an accountant Indonesian Financial Accounting Standards Entities without Public Accountability (SAK ETAP), this facilitates the financial actors in conducting the preparation of financial statements. The advantage of this standard is simpler than the other financial accounting standard; it will be very suitable and appropriate to be applied for the SME.

However, a simple standard is not enough for the principals of SMEs, they still will have difficulty dealing with a book reads too many numbers and code, understand the flow of accounting and accounting code memorization is not an easy task and sometimes reluctant to do. Hire a financial consultant to prepare financial statements are often also not be the solution. So as the development internets as a supporting system for many business processes, 
development of an information system with financial user-friendly interface will be an answer to this problem.

This research tries to provide a solution, namely to build an information system user friendly, easy and convenient to use for the perpetrators of SMEs with financial standard is based on the SAK-ETAP.

\section{Theory}

\section{ME-SMEs}

According to Law No. 20 of 2008 , the so-called small business is an entity that has the criteria as follows:

1) The net worth of more than US $\$ 50,000,000.00$ (fifty million rupiah) up to more than Rp 500,000,000.00 (five hundred million rupiah) not including land and buildings; and

2) It has an annual sales turnover of more than US $\$ 300,000,000.00$ (three hundred million rupiah) up to a maximum of $\mathrm{Rp} 2,500,000,000.00$ (two billion five hundred million rupiah).

Medium Enterprises is the business entity that has the criteria as follows:

1) The net worth of more than US $\$ 500,000,000.00$ (five hundred million rupiah) up to a maximum of Rp 10,000,000,000.00 (ten billion rupiahs), excluding land and buildings; and

2) It has an annual sales turnover of more than Rp2.500.000.000,00 (two billion five hundred million rupiah) up to a maximum of Rp 50,000,000,000.00 (fifty billion rupiah).

While the characteristics of Small and Medium Enterprises, namely:

1) Type of goods or commodities that are cultivated generally already fixed is not easy to change;

2) Location / place of business generally have settled sedentary;

3) In general, is already doing though still modest financial administration, financial companies have started separated with the family finances, have made a business balance sheet;

4) Already have a business license and other legal requirements, including TIN;

5) Human resources (entrepreneurs) have experience in business berwira;

6) Much has access to banks in terms of capital requirements;

7) Most have not been able to make such good business management with business planning.

Medium business criteria:

1) In general, the management and the organization has had a better, more organized and even more modern, with a clear division of tasks, among others, the finance department, marketing department and production department; 
2) Perform financial management by implementing an accounting system regularly, making it easier for auditing and assessment or examination included by banks;

3) Past conduct rules or management and labor organizations, has no Social Security, health care etc;

4) It has all the legal requirements among other neighboring licenses, business licenses, permits spot, TIN, environment management etc;

5) It has access to the sources of bank financing;

6) In general, already have well-trained human resources. (Suhardjono, 2003: 33)

\section{Accounting}

According Kieso (2002: 2), the accounting can be defined precisely by describing three important characteristics of accounting: identification, measurement, of the economic entity to the User concerned. These characteristics have been used to explain the accounting for hundreds of years. However, in the last 30 years of economic entities has changed significantly in terms of both size and complexity, and the users concerned have also increased substantially both in terms of quantity and diversity, communication of financial information as well as the interpretation of the results of the process.

Meanwhile, according to the Accounting Cycle Suharli Michell is a series of process steps of a sequence of transactions and events to reporting at the end of the analysis period and continue the transaction until the next reporting period and so on (2006: 49)

\section{Financial Report}

The purpose of financial statements is to provide information financial position, financial performance, and cash flows of an entity that is useful to a large number of users in making economic decisions by anyone who is not in a position to ask for a special financial report to meet specific information needs. In fulfilling the objectives, financial statements also show what has been done by the management (stewardship) or the accountability of management for the resources entrusted to it.

Characteristics of the qualitative characteristics of information in financial statements, namely (1) Can Be Understood (2) Relevant (3) Materiality (4) Reliability (5) The substance Outperform Forms (6) Consideration Healthy (7) Fittings (8) can be compared (9) Right time (10) balance between Cost and Benefits.

\section{SAK ETAP}

The presence of Financial Accounting Standards Entities without Public Accountability or better known as (SAK ETAP) is expected to provide facilities for SMEs in presenting the financial statements. SAK ETAP also expected constituting an enterprise solution to internal problems, especially for those who only see the results of the management profits without seeing the actual financial condition.

Financial Accounting Standards for Entities without Public Accountability (SAK ETAP) is intended to be used entities without public accountability. SAK ETAP is an entity that: (a) does not have significant public accountability; and (b) publish general purpose financial statements (general purpose financial statement) for external users. Examples of 
external users are owners who are not directly involved in business management, creditors, and credit rating agencies.

3. Discussion and Analysis

Development of an accounting information system based Financial Accounting Standards Entities without Public Accountability or better known as (SAK ETAP) with a user-friendly interface system which is expected to be a solution to the financial statement presentation for entrepreneurs of SMEs. Steps being taken are: (1) Creating the design reports based SMEs (2) Creating a functional design system, and (3) Building systems.

\section{Reporting Design}

Chronology of preparation of financial statements in accounting information systems can be seen as follows:

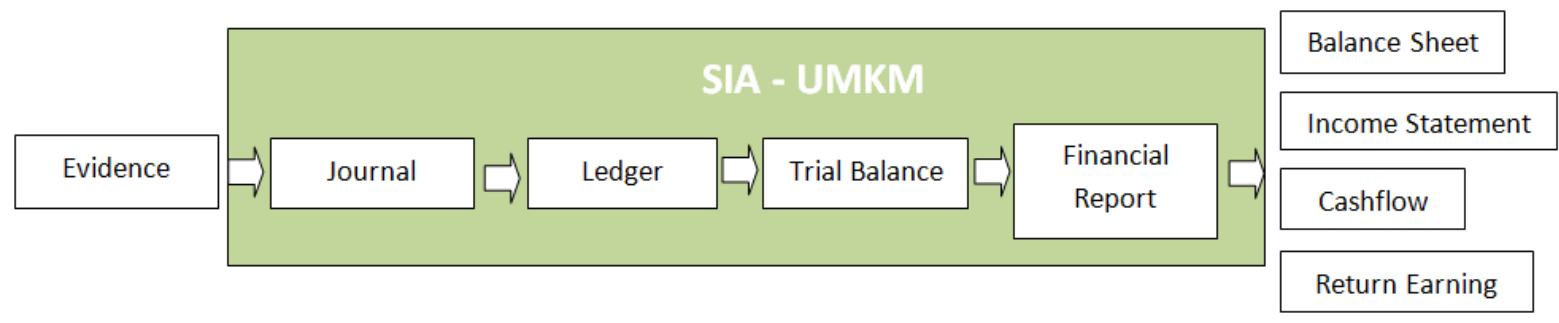

Input is entered into the system, i.e. financial transaction data in detail: Input Data purchases (input purchase order), Sales Data Input (input sales order), Data Input Costs (input expenses) .Input Data Assets (input Fixed Assets) While Output reporting were presented, namely Statements: Balance (Balance Sheet), Profit and Loss (Income Statement), cash flow (cash flow), Retained Earnings (Return Earning), Detailed Receivables (Accounts Receivable), Detail Debt (Accounts Payable), assets (Asset ), and Detailed Cash (Cash).

SMEs do not have to think about how to prepare the counting process in the financial statements. Process and flow accounting will be done automatically by the accounting information system. The perpetrator only needs to input financial data and should certainly do input correctly, because otherwise it would result in financial statements that do not produce valid. After entering financial data, SMEs will choose the menu of reports and receive financial reports. It can be seen in the picture below. It can be seen by the system will greatly facilitate SMEs to prepare financial statements so as to invite investors for their business. 


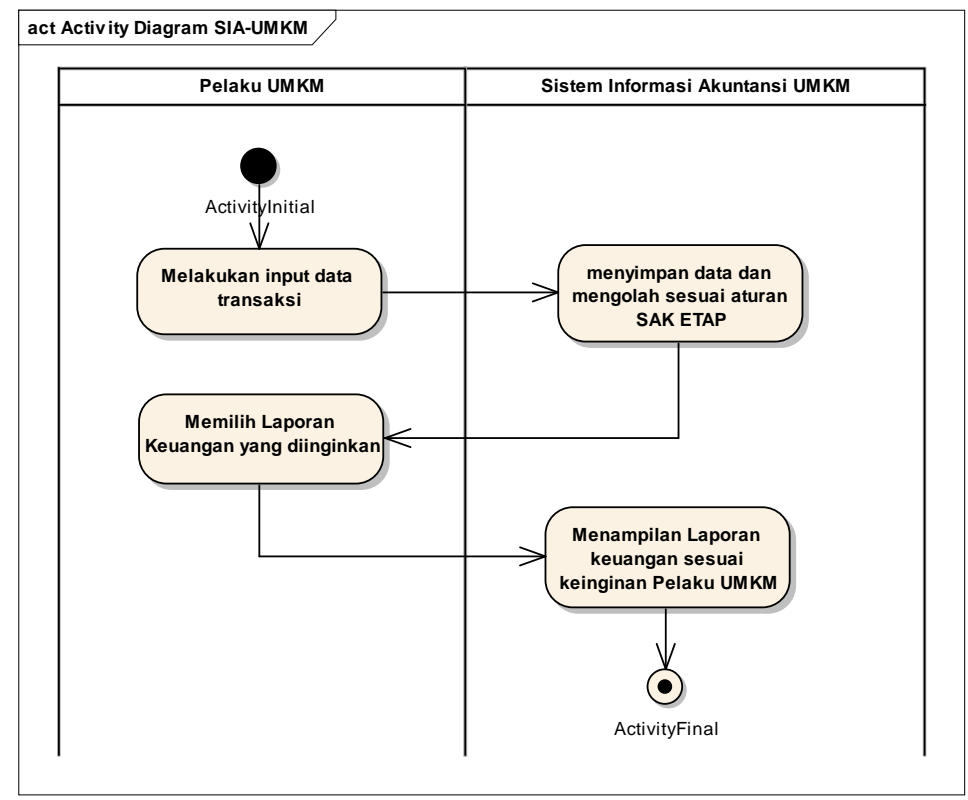

\section{Functional Design System}

Before building the system, it needs to be described thoroughly any functionality of the system. The system can do anything. To make it easier to see the overall functionality of the system, then described using use-case diagram, which can be seen in the figure as follows:

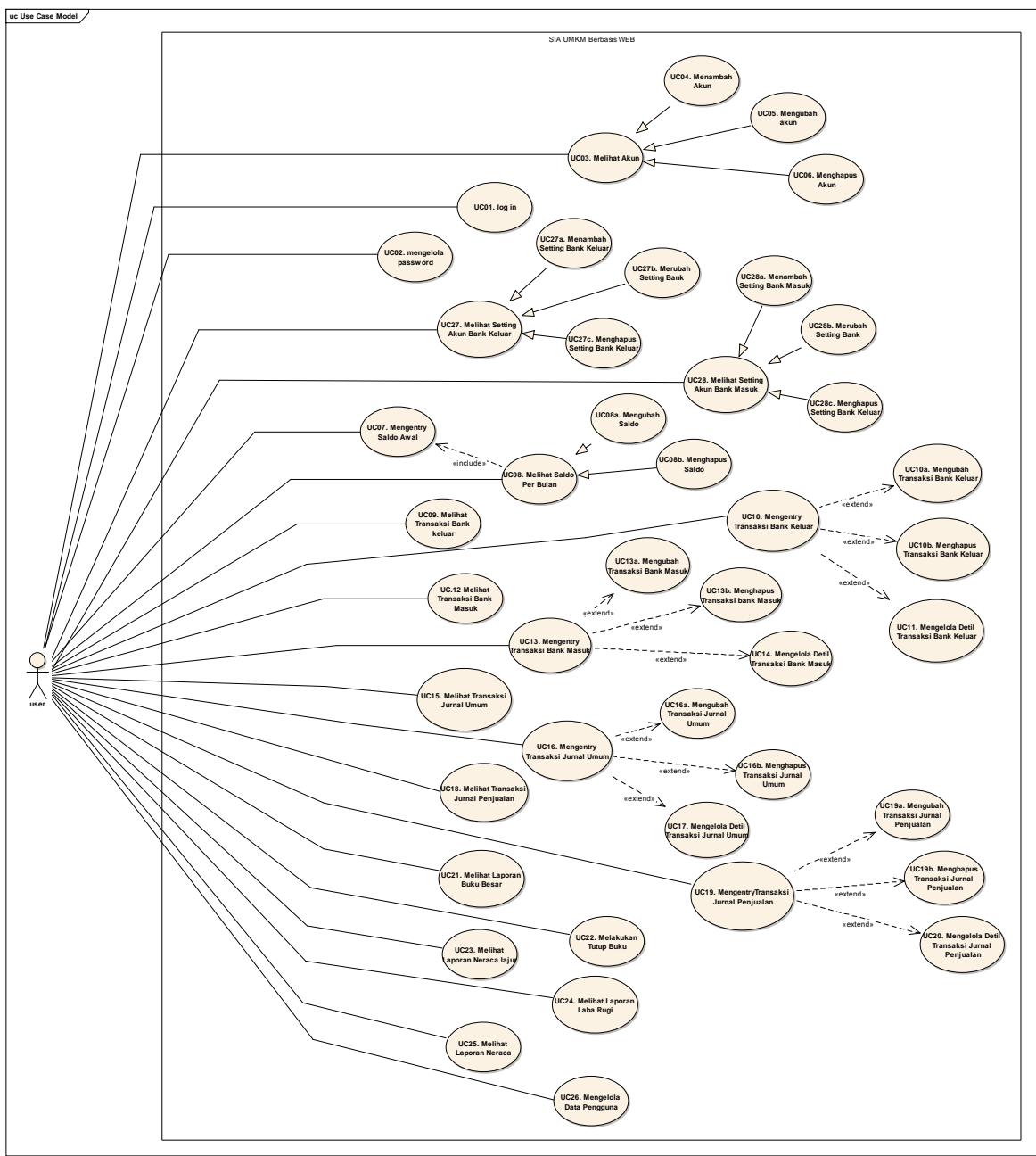




\section{Display Design}

After describing thoroughly for functionality of the system and obtained the simple functions and in accordance with user needs. It is necessary to describe the design of the interface system. System interface design or designs shall see an attractive design, then in the selection of contrasting color and font selection effort is able to make a comfortable user system. The figure below is a view that has been made to create comfortable SMEs.

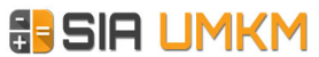

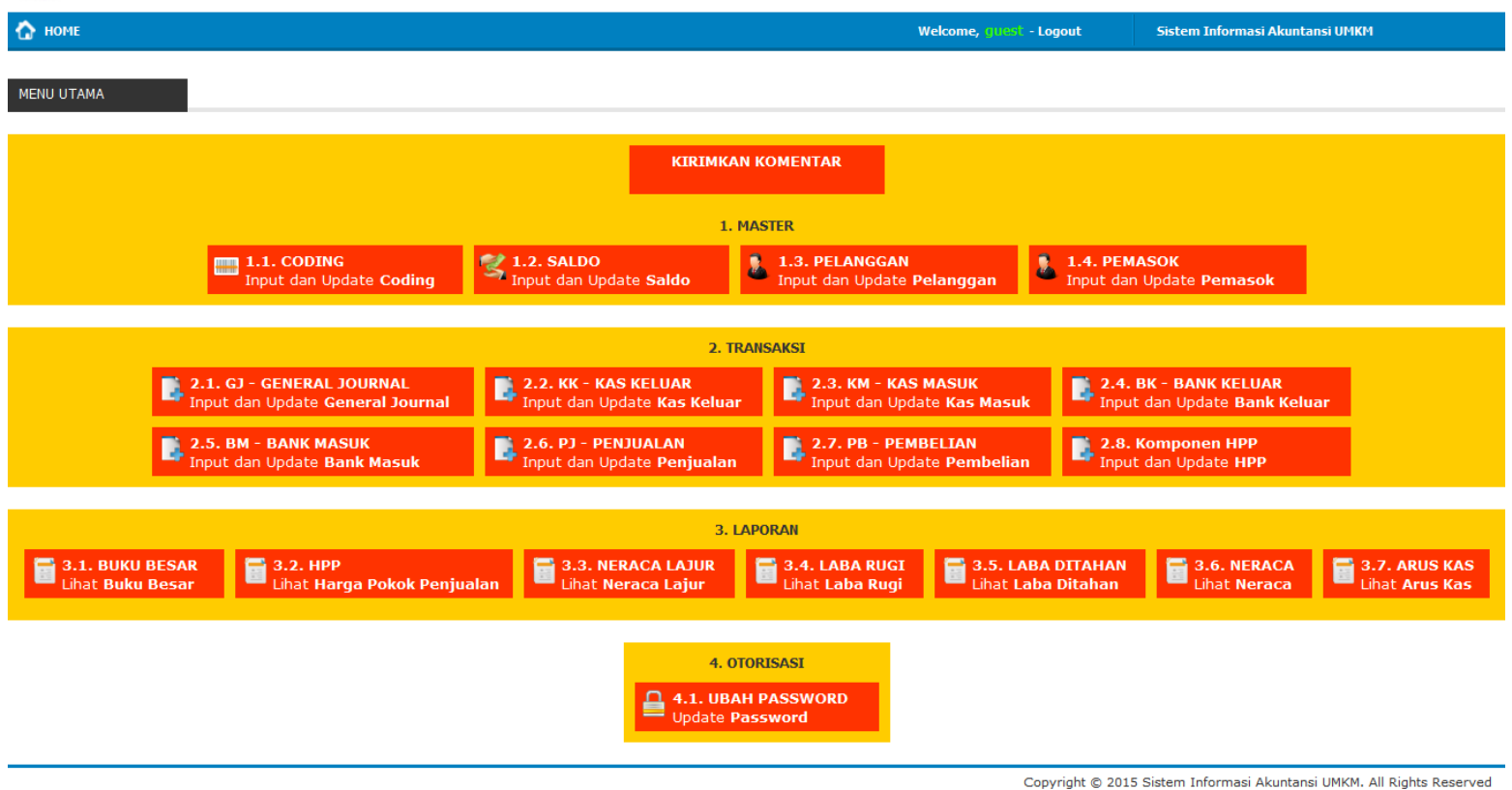

Figure 1 User interface for the main page "Halaman Utama"

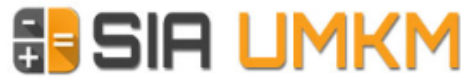

A HOME

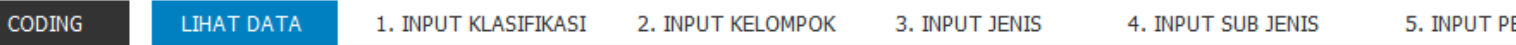

\section{Pencarian Data}

Inputkan Keterangan

\begin{tabular}{|l|l|l|l|l|}
\hline No. & Kode & Keterangan & Posisi & Tambah Data \\
\hline 1 & $100-000-000$ & ASET & DEBET & \\
\hline 2 & $110-000-000$ & ASET LANCAR & DEBET & DEBET \\
\hline 3 & $111-000-000$ & KAS INPUT SUB JENIS \\
\hline 4 & $112-000-000$ & BANK & DEBET & 4. INPUT SUB JENIS \\
\hline 5 & $113-000-000$ & PIUTANG USAHA & DEBET & 4. INPUT SUB JENIS \\
\hline 6 & $114-000-000$ & PERSEDIAAN BARANG DAGANGAN & DEBET & 4. INPUT SUB JENIS \\
\hline 7 & $115-000-000$ & PERSEDIAAN BAHAN BAKU & DEBET & 4. INPUT SUB JENIS \\
\hline
\end{tabular}

Figure 2 User interface for the main page “Kode Rekening” 


\section{⿶ㅐำSIR பMKM}

\section{A Hоме}

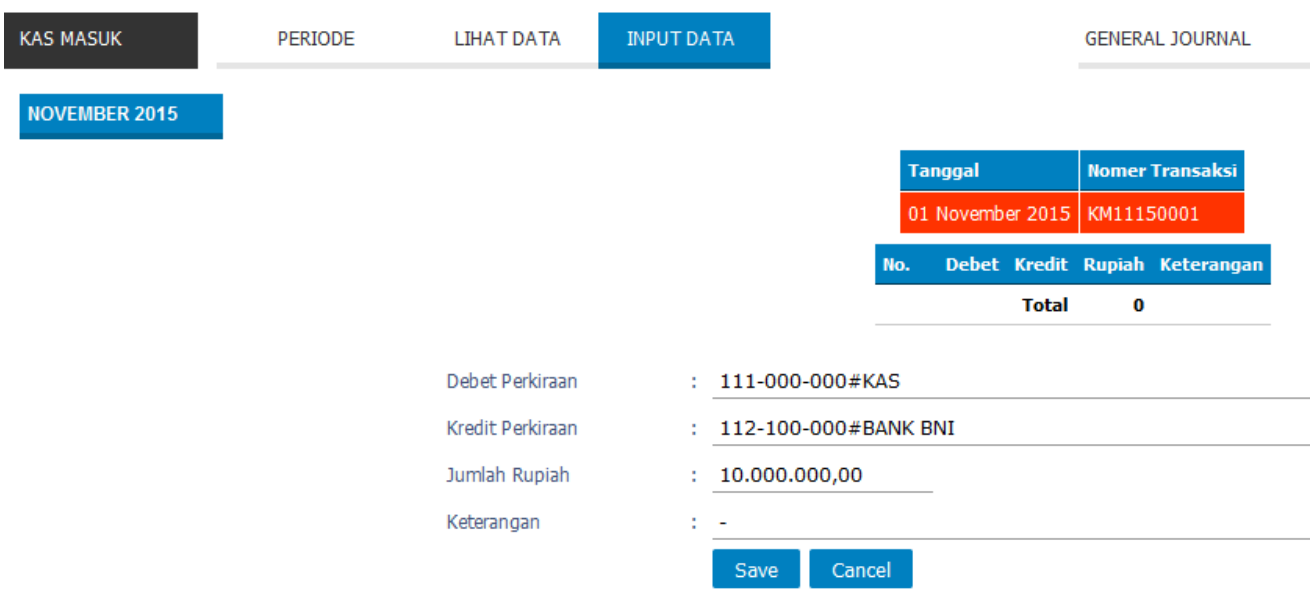

Figure 3 User interface for Sales input page “Kas Masuk”

4. Analysis and Conclusions

SME Accounting Information Systems is an information system that serves the financial statements for the business MSMEs by basing financial statements based SAKETAP (Financial Accounting Standards - standards of financial accounting entities without public accountability). Phase analysis of the system is done using UML diagrams (Unified Modeling Language) i.e. Use Case diagrams and Activity diagrams. From the analysis based on the needs of the system that produced 44 pieces use-case business processes each be detailed by using 56 Activity diagram. Then the system is built using the PHP programming language and $M y S Q L$ database.

Businesspersons SMEs can present the analysis of Cost of Goods Sold (COGS) with ease, so that businesses can SMEs to determine the selling price as a benchmark, businesses SMEs can find the desired profit companies. If the selling price is greater than the cost of sales profits will be obtained, and vice versa if the selling price is lower than the cost of sales will be obtained damages. 


\section{Reference}

Alvin Tranta \&Ryan Bastik Saputro, 2012, MYOB V.18 : Penyelesaian KasusPendekatanBuktiTransaksi,AndiPublisher

Anastasia Diana \& Lilis Setiawati, 2012, Sistem Informasi Akuntansi:Perancangan,ProsesdanPenerapan,AndiPublisher

Cybertron Solution,2010, DatabaseServer2008, AndiPublisher

DewiPratiwidanIrawanSenda,2010,CaraMudahBagiUKMMendobrakKebekuanBinis, ElexMedia

DwiNinggar,MyobAccountingV.18 UntukOrang Awam,Maxicom

GunawanSoedarmanto, 2004, DacEasy Accounting forWindows,Grahallmu

Himayanti, 2007,BelajarSendiri: ZahirAccounting, Elex Media

IAI, 2009, StandardAkuntansi Keuangan - Entitas Tanpa

AkuntanbilitasPublik,Dewan StandardAkuntansiIndonesia- IAI

KristantoAndri, 2003, Perncangan Sistem Informasi dan Aplikasinya, Jogya, Java Media

PressmanRoger S , 2001, Software Engineering : A Practitioner's Approach, Fifth Edition, McGrawHillHigher Education,New York

SalchudinMurpi,BusinessPlan: Praktisdan Dasyat UntukUMKM,LaskarAksara

WilliamDavisS,1983,SistemAnalysis\&Desaign:AStructuredApproachAdditionWestleyPublishingCompany. 